\title{
Thomas L. Casey and Rhode Island's precinctive beetles: Taxonomic lessons and the utility of distributional checklists
}

\author{
Christopher G. Majka', Derek S. Sikes² \\ I clo Nova Scotia Museum, 1747 Summer Street, Halifax, Nova Scotia, Canada B3H 3 A6 2 University of \\ Alaska Museum, 907 Yukon Drive, Fairbanks, Alaska, USA 99775-6960 \\ Corresponding author: Christopher G. Majka (c.majka@ns.sympatico.ca) \\ Academic editor: Jan Klimaszewski | Received 2 February 2009 | Accepted 15 May 2009 | Published 28 September 2009 \\ Citation: Majka CG, Sikes DS (2009) Thomas L. Casey and Rhode Island's precinctive beetles: Taxonomic \\ lessons and the utility of distributional checklists. In: Majka CG, Klimaszewski J (Eds) Biodiversity, Biosystematics, \\ and Ecology of Canadian Coleoptera II. ZooKeys 22: 267-283. doi: 10.3897/zookeys.22.93
}

\begin{abstract}
The sixty-two species of precinctive (reported from the state and from nowhere else) beetles known from Rhode Island, and originally described by Thomas L. Casey, are reviewed. These 62 are reduced to 12 potential candidates, with a further 12 unrevised species awaiting investigation. In terms of the Rhode Island Coleoptera fauna, the present re-evaluation decreases the number of beetles known from the state by 12 to 2,243 species. This information is briefly presented in the context of T.L. Casey's contribution to our knowledge of the North American (and specifically Rhode Island) beetle fauna and the strengths and weaknesses of his taxonomic approach. The utility of distributional checklists, such as the one of the Rhode Island beetle fauna, are discussed. The resolution of taxonomic problems is of central importance to many spheres of biological investigation and accurate distributional checklists are vital in this process. Such checklists are useful in the context of determining biodiversity and environmental monitoring and for many practical purposes such as assisting in identification and highlighting gaps in distribution. Furthermore, data from such checklists also have utility in a variety of zoogeographic investigations, such as contributing to an understanding of latitudinal gradients in species diversity and the geographic basis for proportionate faunal composition. All these are compelling arguments for developing and maintaining such resources.
\end{abstract}

\section{Keywords}

Coleoptera, Rhode Island, Thomas L. Casey, precinctive species, taxonomy, zoogeography, distributional checklists, latitudinal species diversity gradients, proportionate faunal composition 


\section{Introduction}

Thomas Lincoln Casey (1857-1925) was an army engineer by profession. Commencing in 1884, and particularly after his retirement from the army in 1912, he devoted much of his time to the study of Coleoptera. He described over 9,200 species, subspecies, and varieties of beetles. The son of a general, a West Point graduate, a brilliant student, a successful theoretical and applied astronomer, and an avid conchologist and coleopterist, Casey undoubtedly made an enormous contribution to the study of Coleoptera in North America, particularly of the Staphylinidae. When he passed away in Washington, DC on 3 February 1925, he was buried along with his microscope. Intensely observant of detail, his keen intellect and powers of observation served him well in many respects, but his over-attention to small details and minor variations lead to significant shortcomings that marred some of his work, and have bedeviled the work of taxonomists who have followed him. In the first volume of The Coleopterists Bulletin, Ross H. Arnett, Jr. (1947: 67) wrote, "Casey was perhaps the most ardent student of beetles this country has yet produced. Also he was and is the subject of the greatest amount of criticism."

Lindroth (1975) wrote that, "Casey's concept for this unit (species) was apparently considerably different, not only from that of our time, but also from that of his contemporaries and most older authors." Of the 902 "types" of Carabidae studied by Lindroth, he found only 81 that he regarded as valid species.

Seevers (1951) is another author who studied Casey's collections extensively in the course of his revision of Gyrophaena and related genera (Casey described 47 new species in this group of genera within the Aleocharinae). Seevers (1951: 664) synonymized 20 of these and wrote that, "Casey's studies on the Gyrophaenae suffer from several weaknesses that characterize much of his work. One of the chief criticisms of his taxonomy is that he failed to take into account intraspecific variation.... He proposed many species for which no males were available, a practice that greatly complicated the taxonomy of the group.... Casey's practice of including the descriptions in a key to the species did not prove to be satisfactory; diagnostic characters were often obscured by non-essential details. ... Casey's papers give no indication that he attempted to relate the American species ... to their European allies."

Rhode Island was a particular beneficiary of Thomas Casey's attention in that his family farm was located in Saunderstown (currently owned and operated by the Society for the Preservation of New England Antiquities); he collected extensively in the state, and described many beetles from there. As such, as Sikes $(1998,2004)$ has pointed out, part of this legacy are a large number of apparently precinctive (native to the area specified and occurring nowhere else) Rhode Island beetles. Sikes (2004) listed 62 species known from Rhode Island and not reported elsewhere. All of these were species described by Thomas Casey. As Sikes $(1998,2004)$ pointed out, there is no real reason to suppose that these species are actually endemic (i.e., restricted) to Rhode Island since adjacent states share the same environments, and there are no obvious natural barriers to dispersal that would isolate populations in Rhode Island. Nonetheless, until the taxonomic status of these species is resolved, 
the possibility of endemism cannot be excluded. Block Island in the state, continues to support a population of Nicrophorus americanus Olivier, a burying beetle that has otherwise disappeared from all of its eastern range, and Bibloplectus sobrinus (Casey), is a pselaphine rove beetle that is known from only Connecticut and Rhode Island (Sikes 1998).

Bearing this in mind we decided to further investigate this potential suite of precinctive Rhode Island beetles.

\section{Results}

Upon further examination the 62 species reported by Sikes (2004) as known only from Rhode Island can now be placed in the following categories:

1) Synonymized species: these are species names that have been synonymized by authors who have reviewed the respective taxa (Table 1). In all cases these have proved to be species known to occur in jurisdictions beyond Rhode Island.

2) Valid species not confined to Rhode Island: these are species that have been determined to be valid by authors who have reviewed the respective taxa, but that represent species known to occur beyond Rhode Island (Table 1).

3) Valid species known only from Rhode Island: these are species that have (to varying degrees) been treated as valid in recent taxonomic publications, and that have not been reported from outside of Rhode Island (Table 2). They could potentially qualify as precinctive Rhode Island beetles. In most cases, however, they belong to relatively poorly known and largely unrevised genera. In some instances the type specimens have not been critically, comparatively examined to ascertain if they are valid and distinct, and/or collections of these groups at other institutions have not been examined with a view of ascertaining if these species have a wider distribution.

4) Species in unrevised groups: these are species names of unrevised North American taxa that have received little or no critical attention or examination since their description by Casey (Table 2). They could represent any of the above three categories, but, pending revisionary studies, little can be said with respect to their status. Specific notes with respect to a few of these species:

\section{Carabidae}

\section{Olisthopus filicornis Casey, 1913}

This species is treated as valid by Bousquet and Larochelle (1993) and has only been recorded from Rhode Island. There is, however, but a single specimen, a female, making it difficult to determine (without a comprehensive review of the genus) if it is actually different from the widely distributed Olithopus micans LeConte, 1848 (Y. Bousquet, pers. comm.). 
Table I. Synonymized species and valid species not confined to Rhode Island

\begin{tabular}{|c|c|c|c|}
\hline Original Name & Current Name & Distribution & Sources \\
\hline \multicolumn{4}{|c|}{ SYNONYMIZED SPECIES } \\
\hline \multicolumn{4}{|c|}{ Staphylinidae: Aleocharinae } \\
\hline Colpodota acuminata Casey, 1910 & Acrotona egregiella (Casey, 1910) & IA, NY, RI & 1 \\
\hline Colpodota defessa Casey, 1910 & Acrotona egregiella (Casey, 1910) & & 1 \\
\hline Colpodota insulsa Casey, 1910 & Acrotona egregiella (Casey, 1910) & & 1 \\
\hline Arisota insueta Casey, 1910 & Acrotona recondita Erichson, 1839 & $\begin{array}{l}\text { AZ, CA, NY, } \\
\text { PA, RI }\end{array}$ & 1 \\
\hline Neada lubricans Casey, 1910 & Atheta fulgens (Casey, 1907) & RI, WV & 1 \\
\hline Rovalida cribraticeps Casey, 1910 & Halobrecthina opaciceps Bernhauer, 1909 & MA, NJ, RI, VA & 1 \\
\hline Datomicra pellax Casey, 1910 & Atheta hampshirensis Bernhauer, 1909 & $\begin{array}{l}\text { AK, CA, NH, } \\
\text { NY RI; BC, NB, } \\
\text { NS, ON, QC }\end{array}$ & $1,2,4$ \\
\hline Datomicra stilla Casey, 1910 & Atheta dadopora Thomson, 1867 & $\begin{array}{l}\text { AK, NY, PA, RI; } \\
\text { AB, NB, NF, } \\
\text { NS, ON }\end{array}$ & $1,2,3,4$ \\
\hline Dimetrota nuptalis Casey, 1910 & Mocyta fungi (Gravenhorst, 1806) & $\begin{array}{l}\text { MA, ME, MN, } \\
\text { NY, OR, RI; } \\
\text { AB, BC, NF, } \\
\text { NB, NS, ON, } \\
\text { PE, QC }\end{array}$ & $1,2,3,4$ \\
\hline Micrearota pristina Casey, 1910 & Micrearota vestigialis Erichson, 1839 & $\begin{array}{l}\text { IA, NY, PA, RI, } \\
\text { TX }\end{array}$ & 1 \\
\hline Micrearota versuta Casey, 1910 & Micrearota vestigialis Erichson, 1839 & & 1 \\
\hline Dolosota lacertina Casey, 1910 & Acrotona luteola Erichson, 1839 & $\begin{array}{l}\text { DC, IA, MA, } \\
\text { MO, MS, NY, } \\
\text { RI }\end{array}$ & 1 \\
\hline Metaxya bellula Casey, 1910 & Philhygra proterminalis (Bernhauer, 1907) & PA, RI & 1 \\
\hline Sipalia filaria Casey, 1911 & Meotica pallens (Redtenbacher, 1849) & $\begin{array}{l}\text { NJ, RI; BC, NS, } \\
\text { ON }\end{array}$ & $4,5,6$ \\
\hline Stethusa canonica Casey, 1910 & Stethusa dichroa (Gravenhorst, 1802) & $\begin{array}{l}\text { AL, AR, CT, FL, } \\
\text { IA, IL, KS, LA, } \\
\text { MA, MD, ME, } \\
\text { MO, NC, NJ, } \\
\text { NY, OH, PA, } \\
\text { RI, SC, TX, VA, } \\
\text { VT, WV } \\
\end{array}$ & 1,7 \\
\hline Stethusa cynica Casey, 1910 & Stethusa dichroa (Gravenhorst, 1802) & & 1,7 \\
\hline Stethusa videns Casey, 1910 & Stethusa dichroa (Gravenhorst, 1802) & & 1,7 \\
\hline Synaptina tartarea Casey, 1910 & Atheta festinans Erichson, 1839 & $\begin{array}{l}\text { CT, KA, IA, IN, } \\
\text { NY, PA, RI }\end{array}$ & 1 \\
\hline Atheta capella Casey, 1910 & Atheta modesta (Melsheimer, 1844) & $\begin{array}{l}\text { CT, DC, MA, } \\
\text { MI, NY, PA, RI, } \\
\text { VT, WV; AB, } \\
\text { NB, NS, ON, } \\
\text { QC }\end{array}$ & $1,2,4$ \\
\hline
\end{tabular}




\begin{tabular}{|c|c|c|c|}
\hline Original Name & Current Name & Distribution & Sources \\
\hline Atheta fenisex Casey, 1911 & Atheta modesta (Melsheimer, 1844) & & $1,2,4$ \\
\hline Atheta comitata Casey, 1910 & Atheta (Tetropla) frosti Bernhauer, 1909 & $\begin{array}{l}\text { MA, NH, NY, } \\
\text { NC, PA, RI, VT; } \\
\text { BC, NB, NS, } \\
\text { QC }\end{array}$ & $1,2,4$ \\
\hline Atheta modelia Casey, 1911 & Atheta (Tetropla) frosti Bernhauer, 1909 & & $1,2,4$ \\
\hline Atheta nata Casey, 1911 & Atheta (Tetropla) frosti Bernhauer, 1909 & & $1,2,4$ \\
\hline Atheta rhodeana Casey, 1910 & Atheta (Tetropla) frosti Bernhauer, 1909 & & $1,2,4$ \\
\hline Atheta vacillans Casey, 1911 & Atheta (Tetropla) frosti Bernhauer, 1909 & & $1,2,4$ \\
\hline \multicolumn{4}{|c|}{ VALID SPECIES (not confined to RI) } \\
\hline \multicolumn{4}{|l|}{ Staphylinidae: Aleocharinae } \\
\hline Colpodota avia Casey, 1910 & Acrotona avia (Casey, 1910) & RI; NS & 8 \\
\hline Euryprtonota scopula Casey, 1893 & Acrotona scopula (Casey, 1893) & $\begin{array}{l}\text { IA, MO, MS, } \\
\text { NY, PA, RI }\end{array}$ & 1 \\
\hline Atheta limulina Casey, 1911 & Atheta (Dimetrota) limulina Casey, 1911 & NY, RI & 1 \\
\hline Nasirema parviceps Casey, 1893 & Calodera parviceps (Casey, 1893) & $\begin{array}{l}\text { RI; NB, NS, } \\
\text { ON }\end{array}$ & 9 \\
\hline Eucryptusa nanula Casey, 1893 & Leptusa nanula (Casey, 1893) & IA, RI & 10 \\
\hline Oxypoda gnara Casey, 1911 & Oxypoda gnara Casey, 1911 & RI; ON, QC & 2,11 \\
\hline Oxypoda nigriceps Casey, 1894 & Oxypoda nigriceps Casey, 1894 & RI; NB, NS & 2,11 \\
\hline \multicolumn{4}{|l|}{ Staphylinidae: Paederinae } \\
\hline Sunius spectrum Casey, 1905 & Astenus spectrum (Casey, 1905) & $\begin{array}{l}\text { FL, NH, NC, } \\
\text { RI }\end{array}$ & 12,14 \\
\hline Lathrobium rigidum Casey, 1905 & Lathrobium rigidum Casey, 1905 & KS, RI & 14 \\
\hline $\begin{array}{l}\text { Lathrobiella atriventre Casey, } \\
1910\end{array}$ & Lobrathium atriventre (Casey, 1910) & KS, RI & 14 \\
\hline \multicolumn{4}{|l|}{ Staphylinidae: Pselaphinae } \\
\hline $\begin{array}{l}\text { Reichenbachia insolita Casey, } \\
1897\end{array}$ & Reichenbachia insolita Casey, 1897 & RI; ON & 13 \\
\hline
\end{tabular}

\section{Notes:}

Sources: 1, Gusarov (2003c); 2, Gouix and Klimaszewski (2007); 3, Majka and Klimaszewski (2008a); 4, Majka and Klimaszewski (2008b); 5, Gusarov (2002); 6, Klimaszewski et al. (2007); 7, Gusarov (2003a); 8, Majka et al. (2008); 9, Assing (2002, 2008); 10, Pace (1989); 11, Klimaszewski et al. (2006); 12, Frank (1986); 13, Carlton (2003); 14, present study.

Jurisdictions: United States: AK, Alaska; AL, Alabama; AR, Arkansas; AZ, Arizona; CA, California; CT, Connecticut; DC, District of Columbia; FL, Florida; IA, Iowa; IL, Illinois; KS, Kansas; LA, Louisiana; MA, Massachusetts; MD, Maryland; ME, Maine; MN, Minnesota; MO, Missouri; MS, Mississippi; NC, North Carolina; NH, New Hampshire; NJ, New Jersey; NY, New York; OH, Ohio; OR, Oregon; PA, Pennsylvania; SC, South Carolina; TX, Texas; VA, Virginia; VT, Vermont; WV, West Virginia. Canada: AB, Alberta; BC, British Columbia; NB, New Brunswick; NF, Newfoundland; NS, Nova Scotia; ON, Ontario; PE, Prince Edward Island; QC, Québec. 
Table 2. Valid species confined to Rhode Island and unrevised species

\begin{tabular}{|c|c|c|}
\hline Original Name & Current Name & Sources \\
\hline \multicolumn{3}{|c|}{ VALID SPECIES (known only from RI) } \\
\hline \multicolumn{3}{|l|}{ Carabidae: Harpalinae } \\
\hline \begin{tabular}{l|l} 
Olisthopus filicornis Casey, 1913 \\
\end{tabular} & Olisthopus filicornis Casey, 1913 & 1 \\
\hline Olisthopus innuens Casey, 1913 & Olisthopus innuens Casey, 1913 & 1 \\
\hline \multicolumn{3}{|l|}{ Phalacridae } \\
\hline \begin{tabular}{l|l} 
& Stilbus sphaericulus Casey, 1916 \\
\end{tabular} & Stilbus sphaericulus Casey, 1916 & 2 \\
\hline \multicolumn{3}{|l|}{ Staphylinidae: Aleocharinae } \\
\hline Canastota longiclava Casey, 1910 & Atheta longiclava (Casey, 1910) & 3 \\
\hline Hilara nugator Casey, 1911 & Atheta (Microdota) nugator (Casey, 1911) & 3 \\
\hline Donesia temporalis Casey, 1910 & Atheta (Dimetrota) temporalis (Casey, 1910) & 3 \\
\hline Oxypoda lineata Casey, 1893 & Dilacra lineata (Casey, 1893) & 3 \\
\hline Gyrophaena rhodeana Casey, 1906 & Gyrophaena rhodeana Casey, 1906 & 4 \\
\hline Noverota finitima Casey, 1910 & Philhygra finitima (Casey, 1910) & 3 \\
\hline Hilara libens Casey, 1910 & Philhygra finitima (Casey, 1910) & 3 \\
\hline Hilara validiceps Casey, 1910 & Philhygra finitima (Casey, 1910) & 3 \\
\hline Trichiusa pilosa Casey, 1893 & Trichiusa pilosa Casey, 1893 & 3 \\
\hline \multicolumn{3}{|l|}{ Staphylinidae: Oxytelinae } \\
\hline Trogophloeus egregius Casey, 1889 & Carpelimus egregius (Casey, 1889) & 5 \\
\hline Trogophloeus facetus Casey, 1889 & Carpelimus facetus (Casey, 1889) & 5 \\
\hline
\end{tabular}

\section{UNREVISED SPECIES}

\begin{tabular}{|c|c|}
\hline \multirow{2}{*}{\multicolumn{2}{|c|}{$\begin{array}{l}\text { Original Name } \\
\text { Ptiliidae: Acrotrichinae }\end{array}$}} \\
\hline & \\
\hline \begin{tabular}{l|l} 
& Nephanes puritanus Casey, 1924 \\
\end{tabular} & Nephanes puritanus Casey, 1924 \\
\hline \multicolumn{2}{|l|}{ Ptiliidae: Ptiliinae } \\
\hline Ptilium curticolle Casey, 1924 & Ptilium curticolle Casey, 1924 \\
\hline Ptilodina ochracea Casey, 1924 & Ptinella ochracea (Casey, 1924) \\
\hline \multicolumn{2}{|l|}{ Scydmaenidae } \\
\hline Connophron frontale Casey, 1897 & Euconnus (s. str.) frontosus Csiki, 1919 \\
\hline Connophron nimbatum Casey, 1897 & Euconnus (Napochus) nimbatus (Casey, 1897) \\
\hline Connophron osculans Casey, 1897 & Euconnus (Napochus) osculans (Casey, 1897) \\
\hline Connophron limatum Casey, 1897 & Euconnus (Napoconnus) limatus (Casey, 1897) \\
\hline \multicolumn{2}{|l|}{ Staphylinidae: Aleocharinae } \\
\hline Alisalia brevipennis Casey, 1911 & Alisalia brevipennis Casey, 1911 \\
\hline Ischnoglossa abscissa Casey, 1911 & Dexiogyia abscissa (Casey, 1911) \\
\hline Thecturota tenuissima Casey, 1893 & Thecturota tenuissima Casey, 1893 \\
\hline \multicolumn{2}{|l|}{ Staphylinidae: Paederinae } \\
\hline Lathrobium postremum Casey, 1905 & Lathrobium postremum Casey, 1905 \\
\hline Rugilus apicalis Casey, 1904 & Rugilus apicalis Casey, 1904 \\
\hline
\end{tabular}

\section{Notes:}

Sources: 1, Bousquet and Larochelle (1993); 2, Gimmel (2007); 3; Gusarov (2003c); 4, Seevers (1951); 5, Herman (2001). 


\section{Olisthopus innuens Casey, 1913}

This species is treated as valid by Bousquet and Larochelle (1993) and has only been recorded from Rhode Island. There is, however, but a single specimen, a tenereal male, making it difficult to determine (without a comprehensive review of the genus) if it is a distinct species. Y. Bousquet (pers. comm.) feels that the specimen may be conspecific with the widely distributed Olisthopus parmatus (Say, 1823). There are no consistent external structural differences between the holotype of $O$. innuens and $O$. parmatus except that the specimen of $O$. innuens is smaller.

\section{Ptiliidae}

\section{Nephanes puritanus Casey, 1924}

This species was erroneous spelled N. puritans by Sikes (2004).

\section{Ptinella ochracea (Casey, 1924)}

Casey described this species in the genus Ptiliodina Casey, 1924 which is listed by Hall (2001) as a junior synonym of Ptinella Motschulsky, 1872. Poole and Gentilli (1996) treated it in Ptilodina, Downie and Arnett (1996) included it in Pteryx Matthews, 1859, while Sikes (2004) placed it in Ptinella. Since this genus is completely unrevised in North America, the generic assignment of this species is subject to considerable uncertainty.

\section{Scydmaenidae}

\section{Euconnus (s. str.) fromtosus Csiki, 11919}

Casey (1897) described this species as Connophron frontale Casey, 1897, a preoccupied name that was replaced by Euconnus (s. str.) frontosus Csiki, 1919.

\section{Staphylinidae, Aleocharinae}

\section{Acrotona avia (Casey, 1910)}

This species was synonymized with Acrotona subpygmaea Bernhauer, 1909 by Gusarov (2003c), however, the two type specimens of $A$. subpygmaea have the median lobe of the aedeagus missing in the male and a collapsed spermatheca in the female, complicating taxonomic evaluation. Majka et al. (2008), however, revalidated the name A. avia and reported the species from Nova Scotia. 


\section{Acrotona scopula (Casey, 1893)}

This species was also recorded by Casey from several other states in the USA under a variety of names: Dolosota abundans Casey, 1910 [Missouri], Dolosota flaccida Casey, 1910 [Mississippi], Dolosota redundans tergina Casey, 1910 [Pennsylvania], Dolosota secunda Casey, 1910 [Iowa], Dolosota sequax Casey, 1910 [Iowa], and Pancota laetabilis Casey, 1906 [New York] (Gusarov 2003c). All of these names were later transferred to Acrotona and synonymized with $A$. scopula by Gusarov (2003c).

\section{Atheta (Dimetrota) limulina Casey, 1911}

This is a valid species, however, it also now includes a junior synonym, Atheta rusticula Casey, 1911, described by Casey from specimens collected in New York (Gusarov 2003c).

\section{Atheta dadopora Thomson, 1867}

Gusarov (2003b) treated this species as an introduced Palaearctic one, however, Majka and Klimaszewski (2008a, 2008b) regarded it as probably being a widely distributed Holarctic species.

\section{Gyrophaena rhodeana Casey, 1906}

Seevers (1951) revised Gyrophaena in North America and wrote that, "G. rhodeana is probably a valid species of the illiana group" (pp. 686). It has only been recorded from Rhode Island.

\section{Leptusa nanula (Casey, 1893)}

This species is treated as valid by Pace (1989). However, Pace (1989) synonymized Leptusa immunis (Casey, 1911), described from Iowa, with L. nanula. Therefore L. nanula has now also been recorded from Iowa.

\section{Stethusa dichroa (Gravenhorst, 1802)}

This widely distributed species is found in the United States and south through the West Indies to Paraguay and the Galapagos Islands of South America (Gusarov 2003a).

\section{Staphylinidae, Oxytelinae}

\section{Carpelimus egregius (Casey, 1889)}

This species is treated by Herman $(2001,1655)$ as a valid species, known only from its type locality of Newport, Rhode Island. The genus Carpelimus, however, is badly in need of revision in North America (Newton et al. 2001) and C. egregius was listed as a valid name only because no synonymy for it has been published (L. Herman, pers. comm). 


\section{Carpelimus facetus (Casey, 1889)}

This species is treated by Herman $(2001,1655)$ as a valid species, apparently known only from its type locality of Newport, Rhode Island. The genus Carpelimus, however, is badly in need of revision in North America (Newton et al. 2001) and C. facetus was listed as valid name only because no synonymy for it has been published (L. Herman, pers. comm.). In addition to Rhode Island, Moore and Legner (1975) list "Lake Superior?" as a possible locality for this species. Therefore, even if valid, it may not be restricted to Rhode Island.

\section{Staphylinidae: Paederinae}

\section{Astenus spectrum (Casey, 1905)}

This is an apparently valid species that has now been recorded from Florida (Frank 1986), New Hampshire (Chandler 2001) [Rockingham Co., Hampton, 17.I.1933, S.A. Shaw; Strafford Co., 3 mi. SW Durham, 22.IV1982, 9.VI.1982, D.S. Chandler: University of New Hampshire], and North Carolina [Cabarrus Co., Egg Rock Woods, 14.III.1970, T. Daggy, 2 specimens; Mecklenberg Co., West Fork Rocky River, 10.XI.1969, T. Daggy: North Carolina State University].

\section{Lathrobium (s. str.) rigidum Casey, 1905}

The subgenus Lathrobium sensu stricto Gravenhorst, 1802 has remained unrevised since Casey (1905) (Newton et al. 2001). Notwithstanding, there are specimens of this species from Massachusetts [Sherborn, 14.iii.1915, C.A. Frost, under logs] and New York [White Plains, 3.v.1924, JRTB coll.] in the Snow Entomological Museum, indicating that this species is not restricted to Rhode Island.

\section{Lobrathium (Pseudolathra) atriventre (Casey, 1910)}

The subgenus Pseudolathra Casey, 1905 has remained unrevised since Casey (1905) (Newton et al. 2001). Notwithstanding, there are specimens of this species from Oklahoma [Latimer Co., VII.1987, VI.1988, VII.1988, K. Stephan, 4 specimens] in the Snow Entomological Museum indicating that this species is not restricted to Rhode Island.

\section{Discussion}

The Rhode Island beetle fauna. Of the 62 species reported by Sikes (2004) as known only from Rhode Island:

1) 25 nominal species are now known to be synonyms of valid 15 species, none of which are restricted to Rhode Island; 
2) 11 nominal species are now known to be valid species, none of which are restricted to Rhode Island;

3) 14 nominal species, representing 12 species, have (to varying degrees) been treated as taxonomically valid, although the taxonomic status of most of these is as yet far from clear;

4) 12 species belong to genera that are wholly or largely unrevised. Pending revisionary work the status of these cannot be determined.

While not having been synonymized, the taxonomic status of most of the 12 species in the third group - the remaining possible Rhode Island "precinctive" species - is as yet far from clear. Two species (Olisthopus filicornis and O. innuens) are represented by single individuals, and while the genus Olisthopus has not been recently revised, preliminary observations indicate that both of these may be synonymous with other widely distributed species. Two others (Carpelimus egregius and $C$. facetus) have not been subject to taxonomic examination per se and have only been treated as valid species because no synonymies have been published. One species (Gyrophaena rhodeana) has been listed as "probably" a valid species. The other aleocharines (Atheta longiclava, A. nugator, A. temporalis, Dilacra lineata, Philhygra finitima, and Trichiusa pilosa) are members of unrevised genera and are presently taxonomically valid largely by reason of inattention. It is not improbable that in the future, as taxonomic attention is devoted to these species and groups, these species may also fall to synonymy or, if found to be taxonomically valid, may be shown to be distributed beyond the confines of Rhode Island.

Similarly the 12 species in the fourth group, which are completely unrevised and are members of very poorly known groups, may with further investigation also fall to synonymy, or may be shown to be distributed beyond the confines of Rhode Island. In summary the 62 Rhode Island precinctive Coleoptera treated by Sikes (2004) have now been reduced to 12 potential candidates, with a further 12 unrevised species awaiting investigation. In terms of the Rhode Island Coleoptera fauna, the present reevaluation decreases the number of beetles known from the state by 12 , reducing it to 2,243 species (Sikes 2004; Sikes and Webster 2005).

The value and utility of distributional checklists. What is the objective of pursuing such questions? Several useful purposes are served. Taxonomy is, of course, the bedrock of many areas of biology. Resolving questions of systematics and nomenclature lies at the heart of successful scientific communications in relation to many spheres of biological investigation, and the proper characterisation of species lies at the heart of this pursuit. If not correctly resolved, "phantom species" can continue to drift through systematic literature, potentially obscuring legitimate phylogenies. Consequently it is an important goal of taxonomy to investigate un-reviewed taxa and resolve their status.

Dependent on the resolution of such taxonomic studies, are questions of biodiversity. Knowing the faunal composition of a habitat, park, reserve, county, province, state, or country is valuable information. Faunal composition is a reflection of underlying ecological dynamics, environmental circumstances, and historical processes. Thus, a correct understanding of the fauna opens up possible avenues of understanding and 
can suggest profitable courses of investigation and research. To monitor for change (whether as a result of natural processes, or by anthropogenic factors such as climate change, pollution, habitat loss, introduction of species, etc.) one needs to establish baselines from which to measure. Sikes (2004: 1) wrote, "If, a century from now, the checklist were to be revised again, the Rhode Island beetle fauna could become part of a valuable long-term study, with updates and monitoring at 100 -year intervals." Monitoring for ecological change can be useful over intervals of decades as well as of centuries. All these objectives are served by accurate representation of the species composition.

Conservation efforts are also assisted by the development of distributional checklists, that can help to delineate present ranges and hence where conservation efforts should be focused. Sikes (2004: 14) wrote, "For lack of adequate knowledge, globally rare species whose habitat requirements are entirely unknown may be slipping towards extinction in the 'backyards' of New England's most capable naturalists and conservationists. This is an often-cited concern for conservation efforts in the understudied tropics but it is, unfortunately, equally relevant to regions of the world that should already be far better known."

Distributional checklists have a plethora of practical uses. They are of utility to investigators in correlating data sets (i.e., faunistic and floristic) in searching for instructive patterns at their intersections. They can assist in identification by narrowing down the set of likely candidates. A sometimes-neglected point is that distributional checklists can be as informative for what they lack as well as for what they contain. For instance, the lack of records of a species in an area can lead to questions as to whether such an absence represents a real gap, or simply an artifact of to insufficient collecting effort. This can then serve as a springboard for further research.

Distributional checklists can also be of value in the context of zoogeographic investigations. Latitudinal gradients in species diversity are amongst the longest recognized, widely documented, hotly disputed, and least understood phenomena in biogeography. Explaining them is considered by some scientists to be one of the greatest challenges of contemporary ecology (Pianka 1966; Gaston and Blackburn 2000; Pimm and Brown 2004). A large number of closely related and sometime interdependent hypotheses have been advanced to account for this phenomenon such as the mid-domain effect, geographical area hypothesis, the species-energy hypothesis, the climate harshness hypothesis, the climate stability hypothesis, the historical perturbation hypothesis, the evolutionary rate hypothesis, and the effective evolutionary time hypothesis (Pianka 1966; Gaston and Blackburn 2000; Hillebrand 2004; Pimm and Brown 2004).

Hillebrand (2004) conducted a meta-analysis of 581 studies on latitudinal gradients in species diversity. In the present context, it simply worth noting that a preponderance of studies have pertained to birds and molluscs, and relatively few have examined insects. Janzen (1981) focused on Nearctic Ichneumonidae (Hymenoptera) concluding that the peak of species diversity for this group was between $38^{\circ}$ and $42^{\circ} \mathrm{N}$, an exception to the generally observed rule that species diversity decreases with increasing latitude. Gotelli and Ellison (2002) examined species den- 
sity of ants in New England concluding that latitude was the single-most important determinate in species density, even over a limited latitudinal span. Their results gave support to species-energy relationships at regional spatial scales. Despite the species-richness of Coleoptera, the group has been very little investigated with regard to latitudinal gradients.

Figure 1 illustrates a gradient of alpha species richness over geographic latitude as revealed by data from state and provincial distributional checklists. A linear regression of these data yields the equation $\mathrm{Y}=-13.97^{*} \mathrm{X}+834.23$ which is highly significant $(\mathrm{F}=53.26 \mathrm{DF}=1.12 \mathrm{p}=0.0000)$, thus quantifying the relationship of species diversity to geographic latitude for eastern North American Coleoptera. These numbers are in general agreement with the strength of the latitudinal gradient relationship (i.e., the significance of the correlation coefficient) and its slope (i.e., the measure of the latitudinal gradient), found in Hillebrand's (2004) meta-analysis. Although comparable informa-

\section{Latitudinal Variation of Coleoptera in Eastern North America}

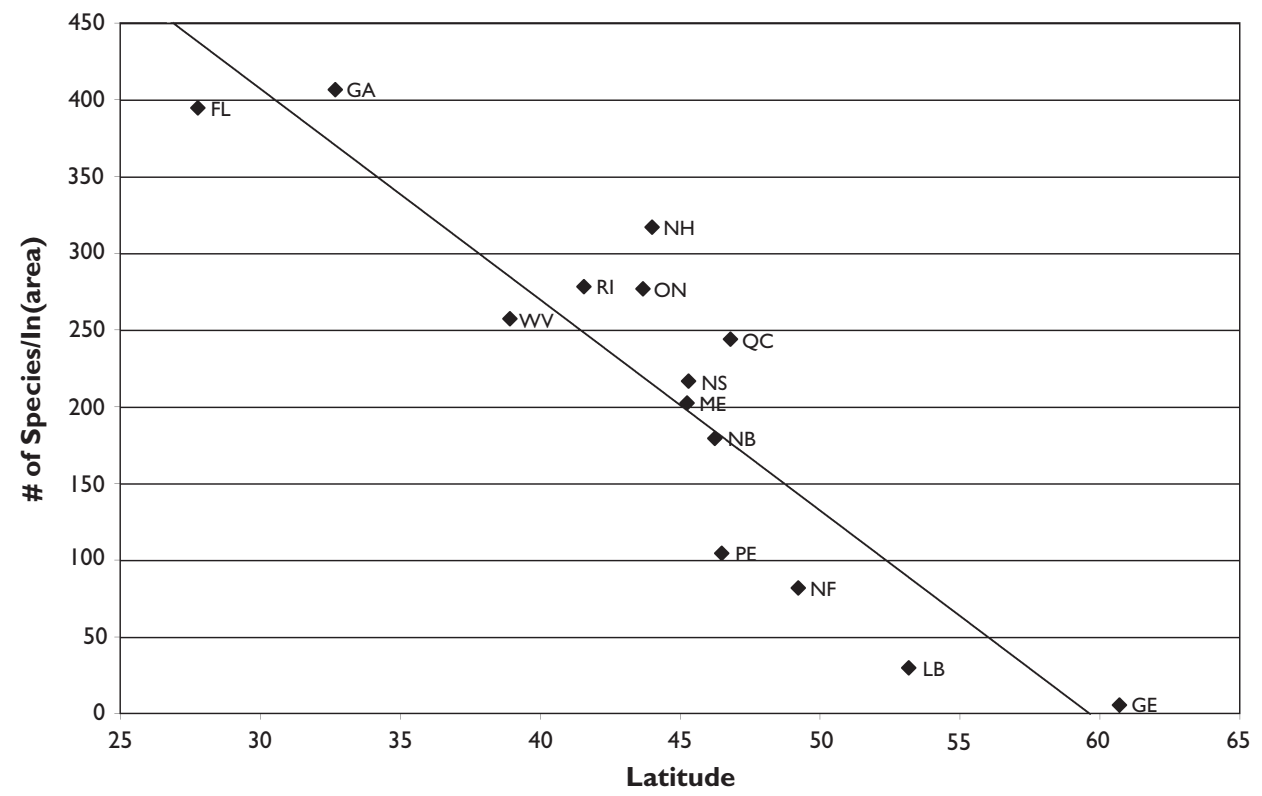

Figure I. Latitudinal Gradient in Species Diversity of Coleoptera in eastern North America

Notes: Data derived from the following sources: FL, Florida (Peck and Thomas 1998); GA, Georgia (Robert Turnbow, unpublished data); GE, Greenland (Böcher 1988); LB, Labrador (Bousquet 1991); ME, Maine (C. Donahue, unpublished data); NB, New Brunswick; NS, Nova Scotia; PE, Prince Edward Island (C.G. Majka, unpublished data); NF, insular Newfoundland (D. Langor, unpublished data); NH, New Hampshire (Chandler 2001); ON, Ontario (Bousquet 1991); QC, Québec (Laplante et al. 1991); RI, Rhode Island (Sikes 2004); WV, West Virginia (Laura Miller, unpublished data).

Since there are large area differences between jurisdictions, and the species-area relationship is nonlinear, Y-axis values are presented as their natural logarithm $(\mathrm{ln})$. The line represents the linear regression of these values $\left(\mathrm{Y}=-13.97^{*} \mathrm{X}+834.23 ; \mathrm{F}=53.26 ; \mathrm{DF}=1,12 ; \mathrm{p}=0.0000\right)$. 
tion from western North American jurisdictions is limited, what data exists for Alaska, British Columbia, and California shows a similar slope but at a higher absolute level.

Another illustration of the utility of distributional checklists is illustrated by Figure 2 which shows the proportionate composition of the ten most abundant North American families of Coleoptera (Marske and Ivie 2003) of the North American beetle fauna as a whole, as well as that found in a number of Canadian provinces (Nova Scotia, New Brunswick, Prince Edward Island, Québec, and Ontario) and American states (Rhode Island, New Hampshire, Florida, and California). Although the proportionate composition of some families (Curculionidae, Cerambycidae, and Elateridae) is relatively constant across northern, southern, eastern, and western jurisdictions, the composition of other families (Staphylinidae and Carabidae) shows marked variations from jurisdiction to jurisdiction. Families such as the Scarabaeidae, Tenebrionidae, and Melyridae exhibit a much greater proportionate representation in southern and western regions than they do in the northeastern portions of North America. Distributional checklist data can therefore yield important insights with respect to the geographical basis of the composition of the North American beetle fauna.

\section{Proportionate Composition of Coleoptera in eastern North America}

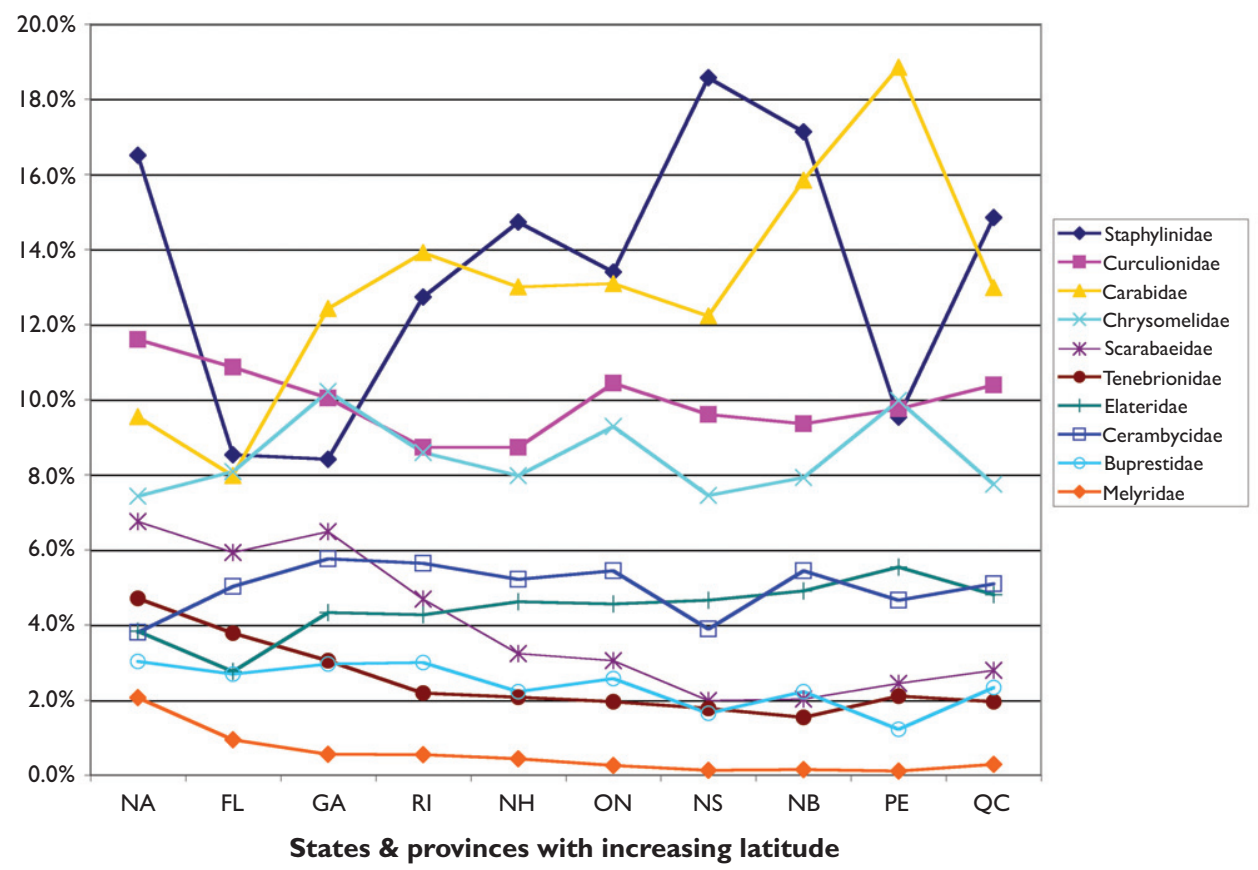

Figure 2. Proportionate of Coleoptera in eastern North America

Notes: Data derived from the following sources: NA, North America (Marske and Ivie 2004); FL, Florida (Peck and Thomas 1998); GA, Georgia (Robert Turnbow, unpublished data); RI, Rhode Island (Sikes 2004); NH, New Hampshire (Chandler 2001); ON, Ontario (Bousquet 1991); NS, Nova Scotia; NB, New Brunswick; PE, Prince Edward Island (C.G. Majka, unpublished data); QC, Québec (Laplante et al. 1991). 
Finally, it should be emphasized that hard-copy publications of checklists, although valuable, are being increasingly augmented by dynamic, database-driven, online resources. Good examples of such resources include the Nearctic Spider Database (Shorthouse 2008) and the Global Biodiversity Information Facility (GBIF 2008), a portal through which data from many institutions are served. Users interested in species occurrence data can extract regional checklists electronically from such sources. The data are, in most cases, specimen-based allowing for misidentifications to be corrected, maps to be generated dynamically, and data to be added and edited over time. These solutions are leading the way towards a future in which distributional biodiversity data are freely and easily available to the public, which, in turn, can provide greater public input (e.g., Esch 2008) and concern with respect to biodiversity conservation issues.

Such patterns illustrate the nature of zoogeographic investigations that are made possible through the compilation of accurate distributional checklists. For all these reasons it is worthwhile to continue fieldwork and taxonomic research that contribute to such resources at all spatial scales.

\section{Acknowledgments}

Many thanks to Volker Assing (Hannover, Germany), Bob Blinn (North Carolina State University), Yves Bousquet (Canadian National Collection of Insects, Arachnids, and Nematodes), Michael Catarino (Santa Barbara Museum of Natural History), Janet Ciegler (Clemson University), Donald Chandler (University of New Hampshire), Charlene Donahue (Maine Forest Service), Zachary H. Falin, (University of Kansas), Lee Herman (American Museum of Natural History), Jan Klimaszewski (Canadian Forest Service), David Langor (Canadian Forest Service), Laura Miller (West Virginia Department of Agriculture), Alfred Newton (Field Museum of Natural History), Michael Thomas (Florida State Collection of Arthropods), Mikael Sörensson (Lund University), and Robert Turnbow (Enterprise, Alabama) for their assistance supplying information, specimen records and in helping to resolve questions of taxonomy and nomenclature. The first author extends thanks to David Christianson, Calum Ewing, and Andrew Hebda (Nova Scotia Museum) for continuing support and encouragement. This work was assisted by the Board of Governors of the Nova Scotia Museum and the Rhode Island Natural History Survey.

\section{References}

Arnett RH, Jr (1947) Brief Biographies: Thomas Lincoln Casey. The Coleopterists Bulletin 1(7): 67-68.

Assing V (2002) A taxonomic and phylogenetic revision of Amarochara Thomson. I. The species of the Holarctic region (Coleoptera: Staphylinidae, Aleocharinae, Oxypodini). Beiträge zur Entomologie 52 (1): 111-204. 
Assing V (2008) The genus Calodera Mannerheim in Canada (Insecta: Coleoptera: Staphylinidae: Aleocharinae). In: Majka CG, Klimaszewski J (Eds) Biodiversity, Biosystematics, and Ecology of Canadian Coleoptera. ZooKeys 2: 203-208. http://pensoftonline.net/zookeys/ index.php/journal/article/view/6/32 [accessed 1.2.2009]

Böcher J (1988) The Coleoptera of Greenland. Meddelelser om Grønland, Bioscience 26: 1-100. Bousquet Y (1991) Checklist of Beetles of Canada and Alaska. Agriculture Canada. Research Branch, Publication 1861/E, Ottawa, Ontario, 430 pp.

Bousquet Y, Larochelle A (1993) Catalogue of the Geadephaga (Coleoptera: Trachypachidae, Rhysodidae, Carabidae including Cicindelini) of America north of Mexico. Memoirs of the Entomological Society of Canada: 167 1-397.

Carlton CE (2003) Revision of Reichenbachia of eastern North America (Coleoptera: Staphylinidae: Pselaphinae). In: Leschen R, Cuccudoro G (Eds) Systematics of Coleoptera: Papers celebrating the retirement of Ivan Löbl. 81 pp.

Casey TL (1897) Coleopterological notices, VII. Annals of the New York Academy of Science 9: 285-684.

Casey TL (1905) A revision of the American Paederini. Transactions of the Academy of Science of St. Louis 15: 17-248.

Chandler DS (2001) University of New Hampshire Insect and Arachnid Collections. http:// insectcoll.unh.edu/ [accessed 1.II.2009]

Downie NM, Arnett RH, Jr (1996) The beetles of northeastern North America. Volume 1. Sandhill Crane Press, Gainesville, Florida, 1721 pp.

Esch M (2008) Lost Ladybug Project seeking a bright spot: Public summoned to track beetles as some types decline. Boston Globe. 29.IX.2008. (see also http://hosts.cce.cornell.edu/ ladybeetles/) [accessed: 4.XII.2008]

Frank JH (1986) A Preliminary Checklist of the Staphylinidae (Coleoptera) of Florida. The Florida Entomologist 69(2): 363-382.

GBIF Data Portal (2008) http://www.gbif.net [accessed 1.II.2009]

Gaston KJ, Blackburn TM (2000) Pattern and Processes in Macroecology. Blackwell Scientific, Oxford, England, 377 pp.

Gimmel ML (2007) World checklist of valid names in Phalacridae. http://entomology.lsu.edu/ lsam/world\%20phalacrid\%20checklist.htm [accessed 1.II.2009]

Gotelli NJ, Ellison AM (2002) Biogeography at a regional scale: determinants of ant species density in New England bogs and forests. Ecology 83: 1604-1609.

Gouix N, Klimaszewski J (2007) Catalogue of aleocharine rove beetles of Canada and Alaska (Coleoptera, Staphylinidae, Aleocharinae. Pensoft, Sofia, Bulgaria, 165 pp.

Gusarov VI (2002) A revision of Nearctic species of the genus Geostiba Thomson, 1858 (Coleoptera: Staphylinidae: Aleocharinae). Zootaxa 81: 1-88. http://www.mapress.com/ zootaxa/2002f/z00081f.pdf [accessed 1.II.2009]

Gusarov VI (2003a) A revision of the Nearctic species of the genus Stethusa Casey, 1910 (Coleoptera: Staphylinidae: Aleocharinae). Zootaxa 239: 1-43. http://www.mapress.com/ zootaxa/2003f/z00239f.pdf [accessed 1.II.2009] 
Gusarov VI (2003b) Revision of some types of North American aleocharines (Coleoptera: Staphylinidae: Aleocharinae), with synonymic notes. Zootaxa 353: 1-134. http://www. mapress.com/zootaxa/2003f/zt00353.pdf [accessed 1.II.2009]

Gusarov VI (2003c) A catalogue of the athetine species of American north of Mexico (Coleoptera: Staphylinidae: Aleocharinae: Athetini). http://nhm.ku.edu/ksem/peet/catalogs/ cataweb.htm [accessed 1.II.2009]

Hall WE (2000) Ptiliidae Erichson, 1845 In: Arnett RH, Jr, Thomas MC (Eds) American Beetles, Volume 1: Archostemata, Myxophaga, Adephaga, Polyphaga: Staphyliniformia. CRC Press, Boca Raton, Florida, 233-246.

Herman LH (2001) Catalogue of the Staphylinidae (Insecta: Coleoptera): 1758 to the end of the Second Millennium. Bulletin of the American Museum of Natural History 265: 1-4218.

Hillebrand H (2004) On the generality of the latitudinal diversity gradient. The American Naturalist 163: 192-211.

Janzen DH (1981) The peak in North American ichneumonid species richness lies between $38^{\circ}$ $\mathrm{N}$ and $42^{\circ} \mathrm{N}$. Ecology 63: 532-537.

Klimaszewski J, Pelletier G, Germain C, Work T, Hébert C (2006) Review of Oxypoda species in Canada and Alaska (Coleoptera, Staphylinidae, Aleocharinae): systematics, bionomics and distribution. The Canadian Entomologist 138: 737-852.

Klimaszewski J, Assing V, Majka CG, Pelletier G, Webster RP, Langor D (2007) Records of adventive aleocharine beetles found in Canada (Coleoptera, Staphylinidae, Aleocharinae). The Canadian Entomologist 139: 54-79.

Laplante S, Bousquet Y, Bélanger, P, Chantal C (1991) Liste des espèces de coléoptères du Quebec. Fabreries supplement 6. 136 pp.

Lindroth CH (1975) Designation of holotypes and lectotypes among ground beetles (Coleoptera: Carabidae) described by Thomas Casey. The Coleopterists Bulletin 29(2): 109-147.

Majka CG, Klimaszewski J (2008a) Introduced Staphylinidae (Coleoptera) in the Maritime Provinces of Canada. The Canadian Entomologist 140(1): 48-72.

Majka CG, Klimaszewski J (2008b) New records of Canadian Aleocharinae. In: Majka CG, Klimaszewski J (Eds) Biodiversity, Biosystematics, and Ecology of Canadian Coleoptera. ZooKeys 2: 85-114. http://pensoftonline.net/zookeys/index.php/journal/article/ view/7/20 [accessed 1.II.2009]

Majka CG, Klimaszewski J, Lauff R (2008) The coastal rove beetles (Coleoptera, Staphylinidae) of Atlantic Canada: a survey and new records. In: Majka CG, Klimaszewski J (Eds) Biodiversity, Biosystematics, and Ecology of Canadian Coleoptera. ZooKeys 2: 115-150. http:// pensoftonline.net/zookeys/index.php/journal/article/view/2/21 [accessed 1.II.2009]

Marske KA, Ivie MA (2003) Beetle Fauna of the United States and Canada. The Coleopterists Bulletin 57: 495-503.

Moore I, Legner EF (1975) A Catalogue of the Staphylinidae of America North of Mexico (Coleoptera). University of California Division of Agricultural Sciences Special Publication No. 3015: 1-514.

Newton AF, Thayer MK, Ashe JS, Chandler DS (2001) Staphylinidae Latreille, 1802. In: Arnett, RH, Jr., and Thomas, MC (Eds) American Beetles, Volume 1: Archostemata, Myxophaga, Adephaga, Polyphaga: Staphyliniformia. CRC Press, Boca Raton, Florida, 272-418. 
Pace R (1989) Monografia del genere Leptusa Kraatz (Coleoptera, Staphylinidae). Memorie del Museo Civico di Storia Naturale di Verona (IIa serie) Sezione Scieze della Vita (A: Biologica) 8. 306 pp.

Peck SB, Thomas MC (1998) A distributional checklist of the beetles (Coleoptera) of Florida. Arthropods of Florida and neighboring land areas. Volume 16. Florida Department of Agriculture and Consumer Services, Division of Plant Industry. Gainesville, Florida. 180 pp. http://www.fsca-dpi.org/Coleoptera/Mike/intro44.htm [accessed 1.II.2009]

Pianka ER (1966) Latitudinal gradients in species diversity: a review of concepts. American Naturalist 100: 33-46.

Pimm SL, Brown JH (2004) Domains of diversity. Science 304: 831-833.

Poole RW, Gentili P (Eds) (1996) Nomina Insecta Nearctica: A check list of the insects of North America. Vol. 1: Coleoptera, Strepsiptera. Entomological Information Services, Rockville, Maryland, 827 pp. http://www.nearctica.com/nomina/nomina.htm [accessed 1.II.2009]

Seevers CH (1951) A revision of the North American and European staphylinid beetles of the subtribe Gyrophaenae (Aleocharinae, Bolitocharini). Fieldiana Zoology 32(10): 659-762.

Shorthouse DP (Ed) (2008) The Nearctic Spider Database. http://www.canadianarachnology. org/data/canada_spiders/ [accessed 1.II.2009]

Sikes DS (1998) Rare and endemic Rhode Island beetles. RINHewS: the Newsletter of the Rhode Island Natural History Survey 6: 8-10.

Sikes DS (2004) The beetle fauna of Rhode Island: an annotated checklist. Rhode Island Natural History Survey, Volume 3. Kingston, Rhode Island. 296 pp.

Sikes DS, Webster RP (2005) Bioinventory of Rhode Island Coleoptera: 45 new records. The Coleopterists Bulletin 59(3): 311-327. 
